CHINA SINCE 1911 


\section{China since 1911}

Richard T. Phillips

Macmillan Education 
ISBN 978-0-333-63880-4 ISBN 978-1-349-24516-1 (eBook)

DOI 10.1007/978-1-349-24516-1

CHINA SINCE 1911

Copyright (C 1996 by Richard T. Phillips

Softcover reprint of the hardcover 1st edition 1996 978-0-333-63879-8

All rights reserved. No part of this book may be used or reproduced

in any manner whatsoever without written permission except in the case of brief quotations embodied in critical articles or reviews.

For information, address:

St. Martin's Press, Scholarly and Reference Division, 175 Fifth Avenue, New York, N.Y. 10010

First published in the United States of America in 1996

ISBN 978-0-312-12941-5 (cloth)

ISBN 978-0-312-12942-2 (paper)

Library of Congress Cataloging-in-Publication Data

Phillips, Richard T.

China since 1911 / Richard T. Phillips.

p. $\mathrm{cm}$.

Includes bibliographical references and index.

ISBN 978-0-312-12941-5.— ISBN 978-0-312-12942-2 (pbk.)

1. China-History-Republic, 1912-1949. 2. China-History-1949-

I. Title.

DS774.P44 1996

$951.04-\mathrm{dc} 20$

95-24654

CIP 


\section{Contents}

$\begin{array}{ll}\text { Acknowledgements } & \text { ix }\end{array}$

Map of the Provinces of Eastern China

in the Mid-Republican Era, c. $1928 \quad$ x

Romanisation and Abbreviations $\quad \mathrm{xi}$

1 INTRODUCTION 1

2 THE EARLY REPUBLIC 11

Politics in $1912 \quad 12$

Politics in $1913 \quad 16$

Politics in $1914 \quad 20$

China and the War in Europe $\quad 22$

Yuan Shikai's Monarchy Project 24

The Death of Yuan Shikai and its Aftermath 26

Parliament and the First World War 28

Wider Trends in Society in the 1910s 32

3 CENTRAL COLLAPSE 40

The Warlords 40

Warlords: Their Territories and Wars 47

Opposition to Warlordism: The May Fourth Movement 53

The Washington Conference 58

The Nationalist and Communist Parties $\quad 59$

The Re-emergence of the Nationalist Party 60

Russian Interest in China 61

Early Communist Activity in China 63

Reorganisation of the Nationalist Party 66

The Nationalist Movement after the Death of
Sun Yixian 
The Northern Expedition 72

Jiang Jieshi's Break with the Communists 74

4 RECONSTRUCTION AND ITS PROBLEMS 84

Establishment of the Nationalist Government 85

Military Allies and Rivals of the Nanjing Government 87

Jiang Jieshi and Nationalist Party Factions 91

Foreign Relations and Nationalism 94

Political Reform and Democracy 96

Economic Policies and People's Livelihood 97

The Nanjing Decade: An Assessment 100

The Communist Party: Rural Soviets and the Sixth $\begin{array}{ll}\text { Congress } & 102\end{array}$

Li Lisan and the Attempt to Retake Cities 106

$\begin{array}{ll}\text { Land Policy } & 109\end{array}$

Military Policy 111

The Long March 113

5 THE SECOND COLLAPSE 117

Japan's Military Advance, 1931-6 119

The Xi'an Incident 123

The Anti-Japanese War $\quad 125$

The End of the Second World War in China 145

$\begin{array}{ll}\text { The Civil War } & 149\end{array}$

6 THE EARLY PEOPLE'S REPUBLIC 161

Consolidation $\quad 162$

Land Reform $\quad 165$

The Political Structure $\quad 167$

Early Foreign Relations 169

Economic Growth and Socialist Transformation 173

$\begin{array}{ll}\text { The Intellectuals } & 178\end{array}$

Foreign Policy 1953-7 181

Problems with the Soviet Model 184

7 THE CHINESE WAY: MARK ONE 187

The Great Leap Forward 188

The Jinmen (Quemoy) Crisis $\quad 191$

The Slowing of the Great Leap Forward 192

The Collapse of the Great Leap Forward 197 
Rebuilding after the End of the Great Leap 199

The Cultural Revolution $\quad 207$

The Ninth Party Congress and After 224

8 THE CHINESE WAY: MARK TWO 230

Politics in 1972 and 1973

Politics in 1974 and $1975 \quad 234$

The Death of Zhou Enlai, and Politics in $1976 \quad 241$

The Death of Mao Zedong, and the Party 1976-8 244

The Third Plenum of the Eleventh Central Committee 249

Changes in Agricultural Policy 250

Party Leadership 1978-87 254

Foreign Relations and the Open Door 259

Political Reforms in the early 1980s 265

Urban Reform in the 1980s 268

Crisis in the late 1980s $\quad 270$

China in the 1990s 276

9 OTHER PARTS OF 'GREATER CHINA' SINCE 1911280

$\begin{array}{ll}\text { Selective Bibliography } & 290\end{array}$

$\begin{array}{ll}\text { Index } & 298\end{array}$ 


\section{Acknowledgements}

For anyone attempting to write a general history of any kind, the greatest debt must be to the innumerable scholars who have explored aspects of that history through their writings and teaching. For this history of China, some of these scholars have been my teachers in the flesh, in particular Martin Bernal, Denis Twitchett, the late John Fairbank and Roy Hofheinz, but most I know only through the printed word. To them all I offer my thanks, for their collection of information and for their pursuit of understanding through interpretation and analysis of that information. I cannot acknowledge them all personally and can only hint at my debt in the Selective Bibliography that closes this book. I can only hope that my assimilation of their knowledge will be within a framework that does not detract from their scholarly standards.

Institutionally I offer thanks to the University of Auckland, which has provided periods of research leave. Two of these were spent at, respectively, the Research School of Pacific Studies at the Australian National University and the Centre for Modern Chinese Studies at the University of Oxford. I thank their directors for the hospitality provided and their university libraries for access to sources. Josie Underhill and Patrice Hicks typed parts of earlier versions of the manuscript, for which much gratitude. To my students at all levels, I owe my continuing enthusiasm for teaching about China and my realisation that even the best textbook is of limited use without the immediacy of talking and thinking about China.

I dedicate this book to the memory of my late mother, Dr Grace Phillips, who agonised and cajoled so that her 10-yearold son might learn to write those ten-line essays beloved of British primary school teachers, little dreaming that one day he would write something a thousand times longer.

Richard T. Phillips 


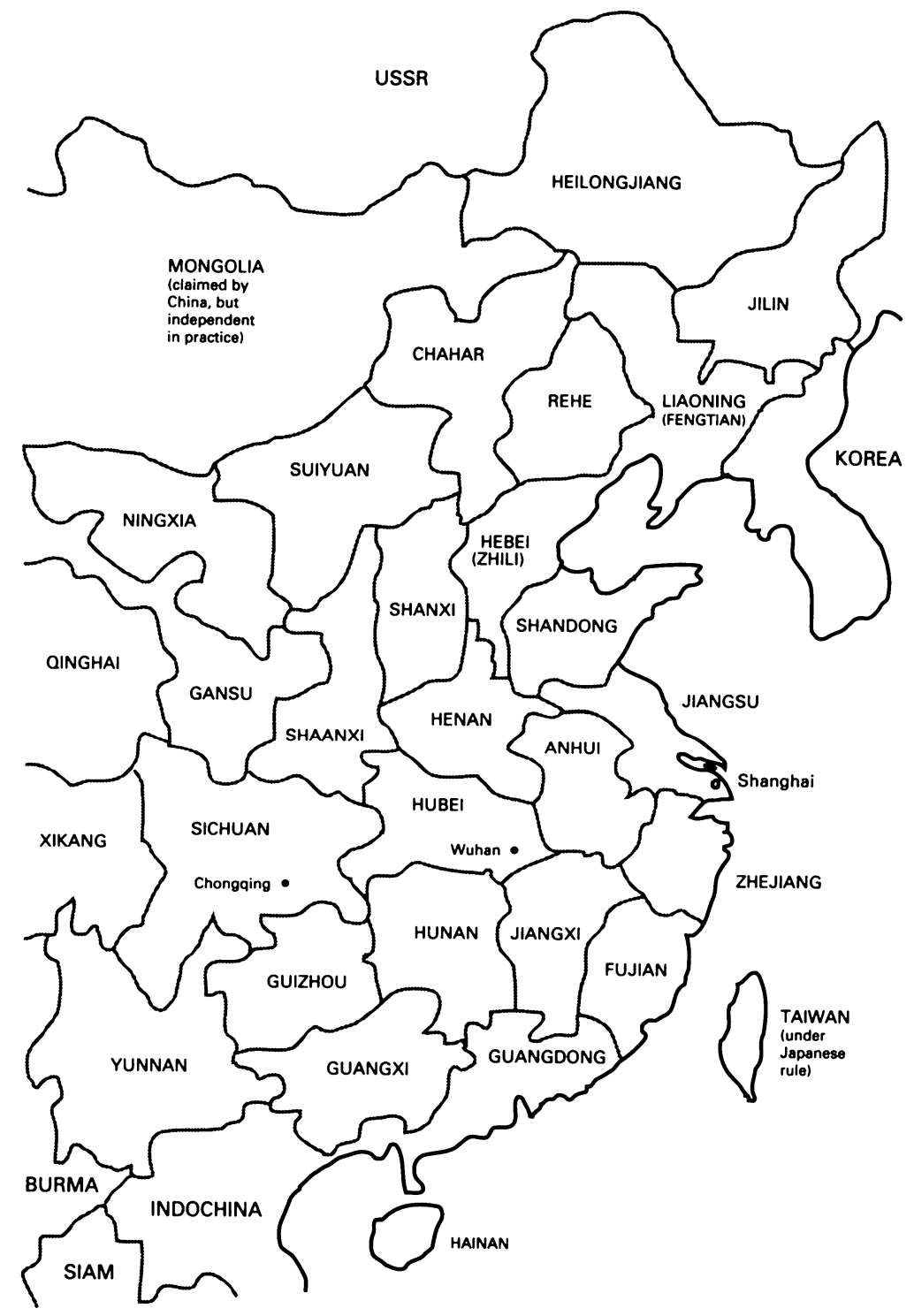

Provinces of Eastern China

in the Mid-Republican Era, c. 1928 


\section{Romanisation and Abbreviations}

This book uses the pinyin system for Chinese personal names throughout, treating all personal names as being read in Mandarin Chinese, with surname first, given name second. This results in the following forms for names of individuals linked to the Nationalist Party who are often known by other romanisations:
Jiang Jieshi $=$ Chiang Kai-shek Jiang Jingguo $=$ Chiang Ching-kuo
Kong Xiangxi $=$ H.H. Kung $\quad$ Li Denghui $=$ Lee Teng-hui Song Ziwen $=$ T.V. Soong Sun Yixian $=$ Sun Yat-sen

Chinese city and province names are also rendered in pinyin, except for the terms Tibet (not Xizang), Manchuria (not Dongbei), Macau (not Aomen), Kowloon (not Jiulong) and Hong Kong (not Xianggang). Two Tibetan places, Lhasa and Aksai Chin, have been left in the forms that are standard in Western atlases. The place-name, Mukden, is noted in the text with its pinyin equivalent, Fengtian, since to call it by its present name of Shenyang would confuse readers who have heard of the Mukden incident (September 1931) from histories of Japan.

Abbreviations have been kept to the minimum, despite their frequent use in Chinese publications for English readers. The following appear:
APC Agricultural Producer Cooperative
CCP Chinese Communist Party
CI Communist International (Comintern)
CPPCC Chinese People's Political Consultative Conference
GMD Guomindang (Chinese Nationalist Party) 
xii ROMANISATION AND ABBREVIATIONS

NRA National Revolutionary Army

PLA People's Liberation Army

PRC People's Republic of China

SEZ Special Economic Zone 